Archives of Agriculture and Environmental Science

\title{
Assessment of heavy metals concentration in water and Tengra fish (Mystus vittatus) of Surma River in Sylhet region of Bangladesh
}

\author{
Ariful Islam¹, Md. Motaher Hossain², Md. Matiur Rahim³, Md. Mehedy Hasan²* (D), Mohammad \\ Tariqul Hassan ${ }^{3}$, Maksuda Begum ${ }^{3}$ and Zobaer Ahmed ${ }^{4}$ \\ ${ }^{1}$ Department of Fisheries, International Institute of Applied Science and Technology (IIAST), Rangpur, BANGLADESH \\ ${ }^{2}$ Department of Fisheries Technology and Quality Control, Sylhet Agricultural University, Sylhet-3100, BANGLADESH \\ ${ }^{3}$ Institute of Food Science and Technology (IFST), Bangladesh Council of Scientific \& Industrial Research (BCSIR), BANGLADESH \\ ${ }^{4}$ Faculty of Fisheries, Sylhet Agricultural University, Sylhet-3100, BANGLADESH \\ *Corresponding author's E-mail: mehedy.sau@gmail.com
}

\section{ARTICLE HISTORY}

Received: 01 April 2019

Revised received: 14 May 2019

Accepted: 24 May 2019

\section{Keywords}

Health risk assessment

Heavy metal

Human consumption

Surma River

Tengra Fish (Mystus vittatus)

\section{ABSTRACT}

The study was carried out to assess the concentration of heavy metals in water and Tengra fish (Mystus vittatus) of the Surma River, the largest water basin ecosystem covering the northeastern parts of Bangladesh. Water and Tengra fish ( $M$. vittatus) samples were collected from a total of six sampling stations in which three sampling stations were in Sylhet district and the rest three were in Sunamganj district. Samples were collected from February 2017 to June 2017 on a monthly basis. Water and Tengra fish (M. vittatus) samples were analyzed for the detection of heavy metals viz., lead $(\mathrm{Pb})$, chromium $(\mathrm{Cr})$ and cadmium $(\mathrm{Cd})$ concentrations. Atomic absorption spectrophotometry was used for the detection of heavy metals after digestion of the samples. $\mathrm{Pb}$ and $\mathrm{Cr}$ were detected from both water and Tengra fish (M. vittatus) samples collected from all the six sampling stations of Sylhet and Sunamganj district. But, Cd was not found both in water and Tengra fish (M. vittatus) during the study period. This study concluded that the detected concentrations of metals ( $\mathrm{Pb}$ and $\mathrm{Cr}$ ) in the studied Tengra fish ( $M$. vittatus) muscles were accepted by the international legislation limits and are safe for human consumption. But in water, $\mathrm{Pb}$ is the only metal that potentially poses the ecological risk to the water body as it exceeds the acceptance level recommended by World Health Organization (WHO). Consequently, close monitoring of metals pollution of the Surma River is recommended with a view to minimizing the health risk of the population that depend on the river for their water and fish supply.

(C)2019 Agriculture and Environmental Science Academy

Citation of this article: Islam, A., Hossain, M.M., Rahim, M.M., Hasan, M.M., Hassan, M.T., Begum, M. and Ahmed, Z. (2019). Assessment of heavy metals concentration in water and Tengra fish (Mystus vittatus) of Surma River in Sylhet region of Bangladesh. Archives of Agriculture and Environmental Science, 4(2): 151-156, https://dx.doi.org/10.26832/24566632.2019.040204

INTRODUCTION

Heavy metals are also known as trace elements is a general collective term which applies to a group of metals and metalloids with an atomic density greater than $4 \mathrm{~g} / \mathrm{cm}^{3}$ or 5 times or greater than water (Duruibe et al., 2007). Heavy metals are one of the serious pollutants in the natural environment due to their toxicity, persistence and bioaccumulation problems (Nouri et al., 2006). Pollution of the natural environment by heavy metals is a worldwide problem (Nuremberg, 1984). Recent years have witnessed vital attention to the issues of serious heavy metals contamination which have been broadly studied (Abou-Arab et al., 2014; Türkmen et al., 2009; Tuzen and Soylak, 2007; Ansari et al., 2005). Heavy metals contamination in the river is one of the major quality issues in many fast-growing cities because maintenance of water quality and sanitation infrastructure did not increase along with population and urbanization growth especially for the developing countries (Ahmed et al., 2010).

Heavy metals may enter in river or aquatic systems from a variety of sources; it can be either natural or anthropogenic 
(human activities) sources (Bem et al., 2003), including industrial or domestic wastewater, application of pesticides and inorganic fertilizers, storm runoff, leaching from landfills, shipping and harbour activities, geological weathering of the earth crust and atmospheric deposition (Yilmaz, 2009). Heavy metals entering the aquatic ecosystem can be deposited in aquatic organisms through the effects of bio-concentration, bioaccumulation via the food chain process and become toxic when accumulation reaches a substantially high level (Huang, 2003). Some heavy metals are toxic to living organisms even at low concentrations. When ingested in excess amounts heavy metals mix with body's biomolecules, like proteins and enzymes to create stable bio-toxic compounds, thereby mutilating their structures and hindering them from the bio-reactions of their functions (Duruibe et al., 2007).

Surma River is one of the major rivers in Bangladesh originated from northeast India when Barak River divided into Surma and Kushiyara River after entering the Bangladesh border. It ends in Kishoregonj district above Bhairab bazar when another river joins with it to form Meghna River. Finally, vast water bodies of this river fall into the Bay of Bengal. With the development of industrialization and rapid expansion of modernization, riverine environment all around the country is in a great threat in term of pollution. The water of the Surma River is also in a polluting trend due to urbanization and industrialization which affecting the water quality for its household and other purposes. The main causes of pollution of Surma River are due to the discharge of wastewater from different small canals which carry wastewater from the small-scale industries, rice husks from rice mills and foodstuffs. The municipal and hospital wastes are also dumped near the riverside (lqbal et al., 2003). Till now, no research was found to be conducted to detect the heavy metal pollution in Surma River. So, there is a need to conduct research to detect the heavy metal concentration in the river water of Surma as this river has economic importance. Surma River is a good source of freshwater fishes and the river water is used for different types of household activities by different communities live nearby the river. Considering all the ditto aspects the present study has been undertaken to find out the presence and concentration of heavy metals ( $\mathrm{Pb}, \mathrm{Cr}$ and $\mathrm{Cd}$ ) in the water and Tengra fish (more common and available fish species in the river) of Surma river- whether it is at an alarming rate or not.

\section{MATERIALS AND METHODS}

\section{Description of sampling sites}

The sampling site was selected on the basis of water color and the distance between the location of the industry and the water body. In this study, total six sampling sites $\left(\mathrm{S}_{1}, \mathrm{~S}_{2}, \mathrm{~S}_{3}, \mathrm{~S}_{4}, \mathrm{~S}_{5}\right.$ and $\left.\mathrm{S}_{6}\right)$ were selected of which three sampling sites were in the Sylhet district $\left(S_{1}, S_{2}\right.$ and $\left.S_{3}\right)$ and the rest three sampling sites were in Sunamganj district $\left(\mathrm{S}_{4}, \mathrm{~S}_{5}\right.$ and $\left.\mathrm{S}_{6}\right)$ (Table 1, 2).

\section{Collection of water and Tengra fish (M. vittatus) samples}

The water and Tengra (Mystus vittatus) fish samples were collected from the selected six sampling stations of Surma River in Sylhet and Sunamganj district. The samples were collected on a monthly basis from February 2017 to June 2017. Water samples were collected manually from a depth of $0.5 \mathrm{~m}$ below the surface. Tengra fish (M. vittatus) sample was collected from the local fishermen while they were harvesting fish using net and boat.

\section{Preservation of water and Tengra fish (M. vittatus) samples}

The water and Tengra fish (M. vittatus) samples were immediately preserved in a refrigerator of the Microbiological Laboratory of Department of Fisheries Technology and Quality Control (FTQC), Sylhet Agricultural University (SAU) after bringing to the laboratory in an insulated ice box. Preserved samples were then sent to Bangladesh Council of Scientific and Industrial Research (BCSIR), Dhaka-1205, Bangladesh in chilled condition using an insulated ice box for further analysis.

\section{Laboratory facilities}

Water and Tengra fish ( $M$. vittatus) samples were tested for heavy metal concentrations namely $\mathrm{Pb}, \mathrm{Cr}$ and $\mathrm{Cd}$. This was done in the laboratory of Toxicology of Institute of Food Science and Technology (IFST), Bangladesh Council of Scientific and Industrial Research (BCSIR), Dhaka-1205, Bangladesh.

Table 1. Sampling sites of Sylhet and Sunamganj district.

\begin{tabular}{ll}
\hline Sampling stations of Sylhet district & Sampling stations of Sunamganj district \\
\hline Kushighat $\left(\mathrm{S}_{1}\right)$ & Chhatak $\left(\mathrm{S}_{4}\right)$ \\
Chalibandar $\left(\mathrm{S}_{2}\right)$ & Dowarabazar $\left(\mathrm{S}_{5}\right)$ \\
Kanishail $\left(\mathrm{S}_{3}\right)$ & Oyezkhali $\left(\mathrm{S}_{6}\right)$ \\
\hline
\end{tabular}

Table 2. The Global Positioning System (GPS) data of the selected sampling stations of Surma River.

\begin{tabular}{llll}
\hline Designation & Site name & Latitude $(\mathrm{N})$ & Longitude (E) \\
\hline $\mathrm{S}_{1}$ & Kushighat & $24^{\circ} 52^{\prime} 36.7^{\prime \prime} \mathrm{N}$ & $91^{\circ} 53^{\prime} 51.8^{\prime \prime} \mathrm{E}$ \\
$\mathrm{S}_{2}$ & Chalibandar & $24^{\circ} 53^{\prime} 09.2^{\prime \prime} \mathrm{N}$ & $91^{\circ} 52^{\prime} 25.0^{\prime \prime} \mathrm{E}$ \\
$\mathrm{S}_{3}$ & Kanishail & $24^{\circ} 54^{\prime} 06.5^{\prime \prime} \mathrm{N}$ & $91^{\circ} 50^{\prime} 20.4^{\prime \prime} \mathrm{E}$ \\
$\mathrm{S}_{4}$ & Chhatak & $25^{\circ} 02^{\prime} 25.8^{\prime \prime} \mathrm{N}$ & $91^{\circ} 40^{\prime} 12.8^{\prime \prime} \mathrm{E}$ \\
$\mathrm{S}_{5}$ & Dowarabazar & $25^{\circ} 03^{\prime} 07.3^{\prime \prime} \mathrm{N}$ & $91^{\circ} 32^{\prime} 20.4^{\prime \prime} \mathrm{E}$ \\
$\mathrm{S}_{6}$ & Oyezkhali & $25^{\circ} 02^{\prime} 45.7^{\prime \prime} \mathrm{N}$ & $91^{\circ} 23^{\prime} 13.8^{\prime \prime} \mathrm{E}$ \\
\hline
\end{tabular}


Preparation of water and Tengra fish (M. vittatus) samples

The water and Tengra fish (M. vittatus) samples were taken from the refrigerator and kept in room temperature for an hour. Then the dorsal and pectoral fins were cut off and viscera were removed from Tengra fish ( $M$. vittatus) samples to reduce the errors. Then the required amount of fish muscle (whole body) was finely chopped and blended manually in a chopping board and thus prepared for further analysis.

Procedure of heavy metals extraction

For the extraction of heavy metal, at first $5 \mathrm{~g}$ finely blended Tengra fish (M. vittatus) sample or $10 \mathrm{~g}$ water sample was weighted and was taken in a crucible. Then $2 \mathrm{ml}$ (4/5 drops) of concentrated $\mathrm{HNO}_{3}$ was added with the sample inside a fume hood. The sample was burned on a hot air plate inside the fume hood. After digestion of the sample on hot air plate, the crucible was kept in a muffle furnace to burn the sample for 5 or 6 hours at $600^{\circ} \mathrm{C}$ temperature to become it ash. Then $10 \mathrm{ml}$ of $\mathrm{HCL}(5 \mathrm{M})$ was added with the ash and boiled it on a hot plate to digest the sample again inside the fume hood. After boiling (samples becomes colorless or transparent) the extracts were filtered into a $100 \mathrm{ml}$ volumetric flask through a $12.5 \mathrm{~cm}$ Whatman No. 1 filter paper and volume it up to $100 \mathrm{ml}$ with de-ionized water inside the fume hood. Finally, the analysis was done by Atomic Absorption Spectrophotometer (AAS).

\section{Analysis of heavy metal concentrations}

The extracted solutions were analyzed by Atomic Absorption Spectrophotometer (AAS) (Model: AA-6300), Shimadzu using argon gas as fuel and air as an oxidizer. The "WizAArd" software was used in the AAS operates on Windows XP/2000. Digested samples were aspirated into the fuel-rich air acetylene flame and therefore the metal concentrations were determined from the calibration curves obtained from standard solutions. Each determination was done from a single analysis and expressed on an "as is" basis.

\section{RESULTS AND DISCUSSION}

Lead concentration in water and Tengra fish (M. vittatus)

Lead $(\mathrm{Pb})$ concentrations of the three sampling stations $\left(\mathrm{S}_{1}, \mathrm{~S}_{2}\right.$ and $\mathrm{S}_{3}$ ) of Sylhet district were found in the range of $0.044 \mathrm{mg} \mathrm{L}^{-1}$ to $0.083 \mathrm{mg} \mathrm{L}^{-1}$ in water and $0.076 \mathrm{mg} \mathrm{kg}^{-1}$ to $0.293 \mathrm{mg} \mathrm{kg}^{-1}$ in Tengra fish (M. vittatus), respectively (Table 3 ). Mean $\mathrm{Pb}$ concentrations of $S_{1}, S_{2}$ and $S_{3}$ were $0.048 \pm 0.003,0.064 \pm 0.014$ and $0.058 \pm 0.011 \mathrm{mg} \mathrm{L}^{-1}$ in water and $0.157 \pm 0.091,0.167 \pm 0.087$ and $0.160 \pm 0.083 \mathrm{mg} \mathrm{kg}^{-1}$ in fish, respectively (Table 3). Mean Pb concentrations both of water $\left(0.064 \pm 0.014 \mathrm{mg} \mathrm{L}^{-1}\right)$ and Tengra fish (M. vittatus) $\left(0.167 \pm 0.087 \mathrm{mg} \mathrm{kg}^{-1}\right)$ were found slightly higher in $\mathrm{S}_{2}$ than $\mathrm{S}_{1}$ and $\mathrm{S}_{3}$.

Lead $(\mathrm{Pb})$ concentrations of the three sampling stations $\left(\mathrm{S}_{4}, \mathrm{~S}_{5}\right.$ and $\mathrm{S}_{6}$ ) of Sunamganj district were found in the range of 0.037 $\mathrm{mg} \mathrm{L}^{-1}$ to $0.072 \mathrm{mg} \mathrm{L}^{-1}$ in water and $0.059 \mathrm{mg} \mathrm{kg}^{-1}$ to $0.355 \mathrm{mg}$ $\mathrm{kg}^{-1}$ in Tengra fish (M. vittatus) (Table 4). Mean $\mathrm{Pb}$ concentrations of $\mathrm{S}_{4}, \mathrm{~S}_{5}$ and $\mathrm{S}_{6}$ of the five months investigation were $0.057 \pm 0.013,0.043 \pm 0.003$ and $0.044 \pm 0.007 \mathrm{mg} \mathrm{L}^{-1}$ in water and $0.196 \pm 0.110,0.123 \pm 0.048$ and $0.127 \pm 0.088 \mathrm{mg} \mathrm{kg}^{-1}$ in Tengra fish (M. vittatus), respectively (Table 4). In $\mathrm{S}_{4}$, the mean $\mathrm{Pb}$ concentrations both in water $\left(0.057 \pm 0.013 \mathrm{mg} \mathrm{L}^{-1}\right)$ and fish $\left(0.196 \pm 0.110 \mathrm{mg} \mathrm{kg}^{-1}\right)$ were found higher than $\mathrm{S}_{5}$ and $\mathrm{S}_{6}$.

Table 3. Mean ( $\pm \mathrm{SD})$ Lead $(\mathrm{Pb})$ concentrations in water $\left(\mathrm{mg} \mathrm{L}^{-1}\right)$ and Tengra fish (M. vittatus) $\left(\mathrm{mg} \mathrm{kg}^{-1}\right)$ of Surma River of Sylhet district.

\begin{tabular}{|c|c|c|c|c|c|c|}
\hline \multirow{3}{*}{ Months } & \multicolumn{6}{|c|}{ Sampling stations } \\
\hline & \multicolumn{2}{|c|}{ Kushighat $\left(\mathrm{S}_{1}\right)$} & \multicolumn{2}{|c|}{ Chalibandar $\left(\mathrm{S}_{2}\right)$} & \multicolumn{2}{|c|}{ Kanishail $\left(\mathrm{S}_{3}\right)$} \\
\hline & Water & Fish & Water & Fish & Water & Fish \\
\hline February & 0.052 & 0.245 & 0.083 & 0.293 & 0.046 & 0.271 \\
\hline March & 0.046 & 0.265 & 0.051 & 0.216 & 0.056 & 0.225 \\
\hline April & 0.047 & 0.105 & 0.069 & 0.129 & 0.073 & 0.108 \\
\hline May & 0.049 & 0.094 & 0.067 & 0.119 & 0.049 & 0.109 \\
\hline June & 0.044 & 0.076 & 0.051 & 0.076 & 0.064 & 0.085 \\
\hline Mean & 0.048 & 0.157 & 0.064 & 0.167 & 0.058 & 0.160 \\
\hline SD & 0.003 & 0.091 & 0.014 & 0.087 & 0.011 & 0.083 \\
\hline
\end{tabular}

Table 4. Mean $( \pm \mathrm{SD})$ Lead $(\mathrm{Pb})$ concentrations in water $\left(\mathrm{mg} \mathrm{L}^{-1}\right)$ and Tengra fish (M. vittatus) $\left(\mathrm{mg} \mathrm{kg}^{-1}\right)$ of Surma River of Sunamganj district.

\begin{tabular}{lcccccc}
\hline \multirow{2}{*}{ Months } & \multicolumn{9}{c}{ Sampling stations } \\
\cline { 2 - 6 } & Water & Fish & Water & Fish & Water & Oyezkhali $\left(\mathbf{S}_{6}\right)$ \\
\cline { 2 - 7 } & 0.044 & 0.247 & 0.044 & 0.188 & 0.037 & 0.208 \\
February & 0.045 & 0.355 & 0.044 & 0.144 & 0.038 & 0.238 \\
March & 0.072 & 0.123 & 0.039 & 0.133 & 0.049 & 0.066 \\
April & 0.056 & 0.181 & 0.046 & 0.076 & 0.040 & 0.066 \\
May & 0.068 & 0.074 & 0.044 & 0.075 & 0.054 & 0.059 \\
June & 0.057 & 0.196 & 0.043 & 0.123 & 0.044 & 0.127 \\
Mean & 0.013 & 0.110 & 0.003 & 0.048 & 0.007 & 0.088 \\
SD & & & & & & \\
\hline
\end{tabular}


In all the stations of Sylhet and Shunamganj district, Lead value in water was found higher than $0.01 \mathrm{mg} \mathrm{L}^{-1}$, recommended limit of $\mathrm{Pb}$ in drinking water (WHO, 2008). This may be due to the discharge of untreated industrial, agricultural and urban effluent to the river. This has already made the water unsuitable for human consumption as according to WHO (2008), $\mathrm{Pb}$ is known to be toxic even at low levels with resultant ill-health effects as chronic exposure has been linked to growth retardation in children (Awofolu et al., 2005; WHO, 2008). A similar result was formed by Tsade (2016) in Kulufo River water, Arba Minch, GamoGofa. He found the Pb concentration ranging from 0.050 to $0.108 \mathrm{mg} \mathrm{L}^{-1}$. Mokaddes et al. (2013) evaluated lower $\mathrm{Pb}$ concentration $\left(0.012 \mathrm{mg} \mathrm{L}^{-1}\right)$ from the river water of Dhaka metropolitan city. Ahmad et al. (2010) reported $\mathrm{Pb}$ concentration varied seasonally and spatially from 58.17 to $72.45 \mu \mathrm{g} / \mathrm{L}$ ( 0.058 to $0.073 \mathrm{mg} \mathrm{L}^{-1}$ ) in the water of Buriganga River which is also in agreement with the present findings. $A$ highest $\mathrm{Pb}$ concentration with mean values of $13.12 \pm 0.1805 \mathrm{mg} \mathrm{L}^{-1}$ was found by Obaroh et al. (2015) during September in River Argungu.

Among the six sampling stations of both Sylhet and Sunamganj district, Chhatak station showed higher $\mathrm{Pb}$ accumulation in tengra fish $\left(0.196 \pm 0.110 \mathrm{mg} \mathrm{kg}^{-1}\right)$. This could be attributed due to the discharge of untreated discharge of the cement factory and agricultural runoff to the water. However, $\mathrm{Pb}$ concentration in Tengra fish from all the sampling station found lower than the WHO recommended limit for fish and fish products of $2.0 \mathrm{mg}$ $\mathrm{kg}^{-1}$ (WHO, 2003). Therefore, it can be concluded that the values of $\mathrm{Pb}$ at both stations were within the safe limit in case of Tengra fish. In some commercial fishes of the Gulf of Cambay, Sharma et al. (2009) found Pb concentration $2.43 \mathrm{mg} \mathrm{kg}^{-1}$ which exceeds the WHO recommended limit. Haque et al. (2003) determined the bioaccumulation of trace metals in Mystus vittatus collected from Buriganga River and found $\mathrm{Pb}$ 1.031$3.3578 \mathrm{mg} \mathrm{kg}^{-1}$ which is higher than the present study. Ahmed et al. (2009) investigated the heavy metal concentration in fish and mussel from the Dhaleshwari River, Bangladesh and found a seasonal variation of $\mathrm{Pb}$ 9.16-13.09 $\mathrm{mg} \mathrm{kg}^{-1}$ which is higher than the present study and as well as WHO recommended limit. Ahmed et al. (2012) determined the level of bioaccumulation of some heavy metals including $\mathrm{Pb}$ in a freshwater fish Ayre (Sperata aor Hamilton, 1822) collected from Rajfulbaria of Dhaleshwari River and compared with FAO standard levels and other related studies and found that the levels of bioaccumulation in the Dhaleshwari River exceeded all the standard levels. Rashid et al. (2012) determined various heavy metals including $\mathrm{Pb}$ in five fish species, viz., Puntius sophore, Glossogobius giuris, Mystus tengara, Macrognathus aculeatus and Channa punctatus from three different locations of Khiru River in Mymensingh and concluded that the concentrations of detected heavy metals in fish muscle were within the permissible limit.

Chromium ( $\mathrm{Cr}$ ) concentration in water and Tengra fish (M. vittatus)

Chromium $(\mathrm{Cr})$ concentrations of the three sampling stations
$\left(\mathrm{S}_{1}, \mathrm{~S}_{2}\right.$ and $\left.\mathrm{S}_{3}\right)$ of Sylhet district were found in the range of 0.008 $\mathrm{mg} \mathrm{L}^{-1}$ to $0.024 \mathrm{mg} \mathrm{L}^{-1}$ in water and $0.015 \mathrm{mg} \mathrm{kg}^{-1}$ to $0.029 \mathrm{mg} \mathrm{kg}$ ${ }^{-1}$ in Tengra fish (M. vittatus) (Table 5). Mean $\mathrm{Cr}$ concentrations of $S_{1}, S_{2}$ and $S_{3}$ of the five months investigation were $0.015 \pm 0.006,0.016 \pm 0.004$ and $0.015 \pm 0.004 \mathrm{mg} \mathrm{L}^{-1}$ in water and $0.020 \pm 0.004,0.022 \pm 0.004$ and $0.021 \pm 0.005 \mathrm{mg} \mathrm{kg}^{-1}$ in Tengra fish (M. vittatus), respectively (Table 5). In $\mathrm{S}_{2}$, the mean $\mathrm{Cr}$ concentrations both in water $\left(0.016 \pm 0.004 \mathrm{mg} \mathrm{L}^{-1}\right)$ and fish $\left(0.022 \pm 0.004 \mathrm{mg} \mathrm{kg}^{-1}\right)$ were slightly higher than $\mathrm{S}_{1}$ and $\mathrm{S}_{3}$.

Chromium concentrations of the three sampling stations $\left(\mathrm{S}_{4}, \mathrm{~S}_{5}\right.$ and S6) of Sunamganj district were found in the range of 0.007 $\mathrm{mg} \mathrm{L}^{-1}$ to $0.047 \mathrm{mg} \mathrm{L}^{-1}$ in water and $0.013 \mathrm{mg} \mathrm{kg}^{-1}$ to $0.054 \mathrm{mg}$ $\mathrm{kg}^{-1}$ in Tengra fish (M. vittatus) (Table 6). Mean $\mathrm{Cr}$ concentrations of $\mathrm{S}_{4}, \mathrm{~S}_{5}$ and $\mathrm{S} 6$ of the five months investigation were $0.019 \pm 0.016,0.015 \pm 0.008$ and $0.013 \pm 0.006 \mathrm{mg} \mathrm{L}^{-1}$ in water and $0.026 \pm 0.016,0.020 \pm 0.06$ and $0.019 \pm 0.005 \mathrm{mg} \mathrm{kg}^{-1}$ in fish, respectively (Table 6). In $\mathrm{S}_{4}$, the mean $\mathrm{Cr}$ concentrations both in water $\left(0.019 \pm 0.016 \mathrm{mg} \mathrm{L}^{-1}\right)$ and Tengra fish (M. vittatus) $\left(0.026 \pm 0.016 \mathrm{mg} \mathrm{kg}^{-1}\right)$ were higher than $\mathrm{S}_{5}$ and $\mathrm{S}_{6}$.

In all the stations of Sylhet and Shunamganj district, $\mathrm{Cr}$ concentration in water was found lower than the recommended limit of $0.05 \mathrm{mg} \mathrm{L}^{-1}$ for $\mathrm{Cr}$ in drinking water (WHO, 2008). This means that consumption of water from the selected Surma River stations was still in safe condition. But, it has already reported that $\mathrm{Cr}$ is very toxic and mutagenic when inhaled and is a known human carcinogen, where long term exposure can cause damage to the liver, kidney, circulatory and nerve tissues, as well as skin irritation (Dayan and Paine, 2001). So, constant monitoring and control program needs to be instituted to protect the high population down the river using the river water as it is being polluted from different sources in the present day. Hassan et al. (2015) found the mean concentration of $\mathrm{Cr} 0.0346$ $\mathrm{mg} \mathrm{L}^{-1}$ in Meghna River water which was also lower than the recommended limit of $\mathrm{Cr}$ given by $\mathrm{WHO}$ for drinking water and is in correlation with the present findings. Das et al., (2011) reported $\mathrm{Cr}$ concentration of Buriganga River and Karnafuli River water was seasonally and spatially from $1.15-6.44 \mu \mathrm{g} \mathrm{L}^{-1}$ (0.0012-0.0065 $\mathrm{mg} \mathrm{L}^{-1}$ ) and 2.75-7.0 $\mathrm{mg} \mathrm{L}^{-1}$ (0.0028-0.007 $\mathrm{mg} \mathrm{L}^{-1}$ ), respectively which are lower than the present study. Leena et al. (2012) measured $\mathrm{Cr}$ in water of Ganga River at selected sites in the middle Ganga plain BDL (Below detection limit) to $1.09 \mathrm{mg} \mathrm{L}^{-1}$.

In all the six sampling stations of both Sylhet and Sunamganj district, the concentration of $\mathrm{Cr}$ recorded in Tengra fish were lower than the recommended limit of $0.15 \mathrm{mg} \mathrm{kg}^{-1}$ for chromium in fish and fish products (WHO, 2008). This means that the consumption of fish from the selected Surma River stations do not pose an immediate threat to the population consuming fish as far as $\mathrm{Cr}$ concentration is concerned.

Sumon (2013) found the mean concentration of chromium $0.665 \pm 0.075 \mathrm{mg} \mathrm{kg}^{-1}$ and $0.2245 \pm 0.0755 \mathrm{mg} \mathrm{kg}^{-1}$ at UPS and PS, respectively in Karnafuli River which is higher than the present study. In fish of Buriganga, the concentration of $\mathrm{Cr}$ was reported 3-13 $\mathrm{g} \mathrm{L}^{-1}\left(0.0030-0.0130 \mathrm{mg} \mathrm{kg}^{-1}\right)$ during the rainy season and $1.2-8 \mu \mathrm{g} \mathrm{L}^{-1}\left(0.0012-0.0080 \mathrm{mg} \mathrm{kg}^{-1}\right)$ in the dry 
season which is lower than the present study and the recommended limit of $\mathrm{Cr}$ given by WHO (Alam, 2003). A range of 5.27 to $7.38 \mathrm{mg} \mathrm{kg}^{-1} \mathrm{Cr}$ concentrations have been reported in fish gills (dry weight basis) of Buriganga River (Ahmad et al., 2010) which is higher than the present findings. Ahmed et al. (2009) investigated the heavy metal concentration in fish and oyster from the Dhaleshwari River, Bangladesh and found a seasonal variation of $\mathrm{Cr}$ ranged from $8.12-9.07 \mathrm{mg} / \mathrm{kg}$ which is higher than the present study. Haque et al. (2003) determined the bioaccumulation of trace metals in $M$. vittatus collected from Buriganga River and found $\mathrm{Cr}$ concentration 2.04-11.79 $\mathrm{mg} \mathrm{kg}^{-1}$ which exceeds the acceptable limit of $\mathrm{Cr}$ given by WHO. Ahmed et al., (2012) determined the level of bioaccumulation of some heavy metals including $\mathrm{Cr}$ in a freshwater fish Ayre (Sperata aor Hamilton, 1822) collected from Rajfulbaria of Dhaleshwari River and compared with FAO standard levels and other related studies and found that the levels of bioaccumulation in the Dhaleshwari River exceeded all the standard levels.

Cadmium (Cd) concentration in water and Tengra fish (M. vittatus)

Presence of Cd wasn't detected in both the water and Tengra fish (M. vittatus) samples collected from all the six stations of Sylhet and Sunamganj district. So, all the six stations $\left(S_{1}, S_{2}, S_{3}, S_{4}, S_{5}\right.$ and $\left.S_{6}\right)$ were reported safe from cd contamination.

Table 5. Mean ( \pm SD) Chromium (Cr) concentrations in water $\left(\mathrm{mg} \mathrm{L}^{-1}\right)$ and Tengra fish (M. vittatus) (mg kg ${ }^{-1}$ ) of Surma River of Sylhet district.

\begin{tabular}{|c|c|c|c|c|c|c|}
\hline \multirow{3}{*}{ Months } & \multicolumn{6}{|c|}{ Sampling stations } \\
\hline & \multicolumn{2}{|c|}{ Kushighat $\left(\mathrm{S}_{1}\right)$} & \multicolumn{2}{|c|}{ Chalibandar $\left(\mathrm{S}_{2}\right)$} & \multicolumn{2}{|c|}{ Kanishail $\left(\mathrm{S}_{3}\right)$} \\
\hline & Water & Fish & Water & Fish & Water & Fish \\
\hline February & 0.024 & 0.026 & 0.022 & 0.028 & 0.021 & 0.029 \\
\hline March & 0.017 & 0.022 & 0.018 & 0.023 & 0.014 & 0.022 \\
\hline April & 0.013 & 0.017 & 0.014 & 0.022 & 0.014 & 0.020 \\
\hline May & 0.011 & 0.018 & 0.017 & 0.019 & 0.013 & 0.018 \\
\hline June & 0.008 & 0.015 & 0.012 & 0.017 & 0.013 & 0.016 \\
\hline Mean & 0.015 & 0.020 & 0.016 & 0.022 & 0.015 & 0.021 \\
\hline SD & 0.006 & 0.004 & 0.004 & 0.004 & 0.004 & 0.005 \\
\hline
\end{tabular}

Table 6. Mean $( \pm \mathrm{SD})$ Chromium (Cr) concentrations in water $\left(\mathrm{mg} \mathrm{L}^{-1}\right)$ and Tengra fish $\left(\mathrm{mg} \mathrm{kg}^{-1}\right)$ (M. vittatus) of Surma River of Sunamganj district.

\begin{tabular}{lcccccc}
\hline \multirow{2}{*}{ Months } & \multicolumn{4}{c}{ Sampling stations } \\
\cline { 2 - 7 } & \multicolumn{2}{c}{ Chhatak $\left(\mathbf{S}_{4}\right)$} & \multicolumn{2}{c}{ Dowarabazar $\left(\mathbf{S}_{5}\right)$} & \multicolumn{2}{c}{ Oyezkhali $\left(\mathbf{S}_{6}\right)$} \\
\cline { 2 - 7 } & Water & Fish & Water & Fish & Water & Fish \\
\hline February & 0.047 & 0.054 & 0.026 & 0.028 & 0.022 & 0.029 \\
March & 0.021 & 0.026 & 0.021 & 0.023 & 0.013 & 0.019 \\
April & 0.011 & 0.019 & 0.011 & 0.019 & 0.011 & 0.017 \\
May & 0.011 & 0.015 & 0.008 & 0.016 & 0.011 & 0.017 \\
June & 0.007 & 0.015 & 0.007 & 0.013 & 0.007 & 0.015 \\
Mean & 0.019 & 0.026 & 0.015 & 0.020 & 0.013 & 0.019 \\
SD & 0.016 & 0.016 & 0.008 & 0.006 & 0.006 & 0.005 \\
\hline
\end{tabular}

Conclusion

The results of the present study showed that the heavy metals concentrations in Tengra fish (M. vittatus) was in a permissible limit in terms of food safety issue especially chemical hazards. However, heavy metals pollution in river water was found in alarming condition as the lead concentration has crossed the acceptable limits of $0.01 \mathrm{mg} \mathrm{L}^{-1}$ (WHO). So, it is high time to prevent heavy metals pollution in Surma River as the river serves as a source of drinking water, irrigation and fish for the local inhabitants. For this, it is necessary to create awareness among the public as well as the policymakers about the importance of installing the Effluent Treatment Plant (ETP) in various polluting industries. Besides, the anthropogenic sources and agricultural runoff should be reduced. In this study, heavy metals were detected only in Tengra fish (M. vittatus), so other types of fish should be analyzed for heavy metals to check the level of pollution. The concentration of other heavy metals like mercury, arsenic, copper, iron, nickel and others that were not studied should be assessed.

\section{ACKNOWLEDGEMENTS}

The authors are grateful to the Ministry of Science and Technology of Bangladesh for providing fund to conduct the research.

\section{Conflict of interest}

The authors declare there are no conflicts of interest.

Open Access: This is an open access article distributed under the terms of the Creative Commons Attribution 4.0 License, which permits unrestricted use, distribution, and reproduction in any medium, provided the original author(s) if the sources are credited. 


\section{REFERENCES}

Abou-Arab, A.A.K., Abou Donia, M.A., Nevin, E., Sharaf and Sherif, R. and Mohamed (2014). Lead levels in human blood as biological test in different Egyptian environments. World Journal of Medical Sciences, 10: 392-399, https://doi.org/10.5829/idosi.wjms.2014.10.4.1144

Ahmad, M.K., Islam, S., Rahman, S., Haque, M.R. and Islam, M.M. (2010). Heavy metals in water, sediment and some fishes of Buriganga River, Bangladesh. International Journal of Environmental Resources, 4: 321-332, https://doi.org/10.22059/ijer.2010.24

Ahmed, A.T.A., Mandal, S., Chowdhury, D.A., Tareq, A.R.M. and Rahman, M.M. (2012). Bioaccumulation of some heavy metals in Ayre fish (Sperata aor Hamilton, 1822), sediment and water of Dhaleshwari River in dry season. Bangladesh Journal of Zoology, 40: 147-153, https://doi.org/10.3329/bjz.v40i1.12904

Ahmed, M., Ahmed, A.A.M. and Mazumder, R.K. (2010). Deterioration of water quality of Surma River influenced by Natural canals passing through Sylhet City of Bangladesh. Proc. of International Conference on Environmental Aspects of Bangladesh (ICEAB10), Japan.

Ahmed, M.K., Ahmed, S., Rahman, S., Haque, M.R. Islam, M.M. (2009). Heavy metal concentrations in water, sediments and their bioaccumulations in some freshwater fishes and mussel in Dhaleshwari River, Bangladesh. Terrestrial and Aquatic Environmental Toxicology, 3(1): 33-41.

Alam, K. (2003). Cleanup of the Buriganga River: Integrating the Environment into Decision Making, PhD Dissertation, Peth, Mordoch University. pp. 120; http://researchrepository.murdoch.edu.au/id/eprint/22

Ansari, T.M., Mahboob, S., Hanif, T., Arif, M. and Salam, A. (2005) Dry ashing or wet digestion: A comparative study for estimation of zinc and calcium in freshwater fish samples by atomic absorption spectrometry. Journal of the Chemical Society of Pakistan, 27: 90-94.

Awofolu, O.R., Mbolekwa, V.M. and Fatoki, O.S. (2005). Levels of trace metals in water and sediment from Tyume River and its effects on an irrigated farm and. African Journals Online, 31: 87-94, http://dx.doi.org/10.4314/wsa.v31i1.5124

Bem, H., Gallorini, M., Rizzio, E. and Krzemin, S.M. (2003). Comparative studies on the concentrations of some elements in the urban air particulate matter in Lodz City of Poland and in Milan, Italy. Environment International, 29: 423428, https://doi.org/10.1016/S0160-4120(02)00190-3

Das, M., Ahmed, M.K., Islam, M.S., Islam, M.M. and Akter, M.S. (2011). Heavy metals in industrial effluents (tannery and textile) and adjacent rivers of Dhaka City, Bangladseh. Terrestrial and Aquatic Environmental Toxicology, 5: 8-13.

Dayan, A.D. and Paine, A.J. (2001). Mechanisms of chromium toxicity, carcinogenicity and allergenicity: Review of the literature from 1985 to 2000 . Human and Experimental Toxicology, 20: 439-451, https://doi.org/10.1191/096032701682693062

Duruibe, J.O., Ogwegbu, M.O.C. and Egwurugwu, J.N. (2007). Heavy metal pollution and human biotoxic effects. International Journal of Physical Science, 2: 112-118, http://www.academicjournals.org/IJPS

Haque, W., Ahmed, A.T.A., Tarafdar, S.A., Akhter, S. and Quraishi, S.B. (2003). Trace elements in two small fishes (Puntius sophore (Hamilton) and Mystus vittatus (Bloch) of Buriganga river, Balu river and Ichamati beel. Bangladesh Journal of Zoology, 31(2): 247-251.
Hassan, M., Rahman, M.A.T.M.T., Saha, B. and Kamal, A.K.I. (2015). Status of heavy metals in water and sediment of the Meghna River, Bangladesh. American Journal of Environmental Sciences, 11: 427-439, https://doi.org/10.3844/ajessp.2015.427.439

Huang, W.B. (2003). Heavy metal concentrations in the common benthic fishes caught from the coastal waters of Eastern Taiwan. Journal of Food and Drug Analysis, 11: 324.

Iqbal, S.A., Haque, E., Iqbal, M. and Chowdhury, M.A.I. (2003). Water quality assessment of Surma River in Sylhet city. Journal of Chemical Engineering, 23: 63-66, https://doi.org/10.3329/jce.v23i0.5574

Leena, S., Choudhary, S.K. and Singh, P.K. (2012). Status of heavy metal concentration in water and sediment of river Ganga at selected sites in the middle Ganga plain. International Journal of Research in Chemistry and Environment, 2: 236-243.

Mokaddes, M.A.A., Nahari, B.S. and Baten, M.A. (2013). Status of heavy metal contamination of river water of Dhaka Metropolitan City. Journal of Environmental Science \& Natural Resources, 5: 349-353, https://doi.org/10.3329/jesnr.v5i2.14842

Nouri, J., Mahvi, A.H., Jahed, G.R. and Babaei, A.A. (2006). Regional distribution pattern of groundwater heavy metals resulting from agricultural activities. Journal of Environmental Geography, 55: 1337-1343, https://doi.org/10.1007/s00254-007-1081-3

Nuremberg, H.W. (1984). The voltammetric approach in trace metal chemistry of natural waters and atmospheric precipitation. Analytica Chimica Acta, 164: 1 -21, https://doi.org/10.1016/S0003-2670 (00)85613-5

Obaroh, I.O., Abubakar, U., Haruna, M.A. and Elinge, M.C. (2015). Evaluation of some Heavy metals concentration in River Argungu. Journal of Fisheries and Aquatic Science, 10: 581-586, https://doi.org/10.3923/jfas.2015.581.586

Rashid, H., Hasan, M.N., Tanu, M.B., Parveen, R., Sukhan, Z.P., Rahman, M.S. and Mahmud, Y. (2012). Heavy metal pollution and chemical profile of Khiru River, Bangladesh. International Journal of Environment, 2: 57-63.

Sharma, J. and Fulekar, M.H. (2009). Potential of Citrobacter freundii for bioaccumulation of heavy metal-copper. Biology and Medicine, 1(3): 7-14

Sumon, K.A. (2013). Bioaccumulation of heavy metals in aquatic Fauna collected from contaminated waters of the river Karnafuli in the south-east Coast of Bangladesh. MS Thesis, Bangladesh Agricultural University.

Tsade, H.K. (2016). Atomic absorption spectroscopic determination of heavy metal concentrations in Kulufo River, Arbaminch, Gamo Gofa, Ethiopia. Journal of Environmental Chemistry, $\quad 3$ 177, https://doi.org/10.41722380-2391.1000177

Türkmen, M., Turkmen, A., Tepe, Y., Töre, Y. and Ates, A. (2009). Determination of metals in fish species from Aegean and Mediterranean Seas. Food Chemistry, 113: 233-237, https://doi.org/10.1016/j.foodchem.2008.06.071

Tuzen, M. and Soylak, M. (2007). Determination of trace metals in canned fish marketed in Turkey. Food Chemistry, 101: 1378-1382, https://doi.org/10.1016/j.foodchem.2006.03.044

WHO. (2003). Chromium, zinc, lead, in drinking-water. Background document for preparation of WHO Guidelines for drinking-water quality, Geneva, (WHO/ SDE/WSH/03.04/4).

WHO. (2008). Guidelines for Drinking-water Quality; 3rd Edition 1-459.

Yilmaz, F. (2009). The comparison of heavy metal concentrations ( $\mathrm{Cd}, \mathrm{Cu}, \mathrm{Mn}, \mathrm{Pb}$, and $\mathrm{Zn}$ ) in tissues of three economically important fish (Anguilla anguilla, Mugil cephalus and Oreochromis niloticus) inhabiting Köycegiz Lake-Mugla (Turkey). Turkish Journal of Science and Technology, 4: 7-15. 